Edunomika - Vol. 03, No. 02 (Agustus 2019)

\title{
ANALISIS KINERJA KARYAWAN PALANG MERAH INDONESIA (PMI) KOTA SURAKARTA
}

\author{
V. Noerhastami Retnowati, Sudarwati, Istiqomah \\ FEB Universitas Islam Batik Surakarta \\ e-mail: noerhastamiretnowati333@gmail.com
}

\begin{abstract}
ABSTRAK : Penelitian ini bertujuan untuk mengetahui pengaruh kepemimpinan, kepuasan kerja dan motivasi terhadap kinerja karyawan yang ada di Palang Merah Indonesia ( PMI ) Kota Surakarta. Jenis penelitian termasuk penelitian deskriptif kuantitatif. Penelitian dilakukan di Palang Merah Indonesia ( PMI ) Kota Surakarta dengan waktu selama kurang lebih 3 bulan, dengan sumber data Data Primer dan Data sekunder. Populasi sampel seluruh Karyawan di Palang Merah Indonesia (PMI) Kota Surakarta sebanyak 85 orang. Dilakukan dengan Metode pengumpulan data Observasi, Kuesioner, Dokumentasi dan Studi Pustaka. Uji instrumen Validitas dan Realiabilitas. Uji Hipotesa Uji F, Uji $t$ dan uji Determinan. Hasil penelitian menunjukan kepemimpinan, kepuasan kerja dan Motivasi secara simultan mempunyai pengaruh yang signifikan terhadap kinerja karyawan di Palang Merah Indonesia ( PMI ) Kota Surakarta. Hal ini di buktikan dengan F hitung > $F$ tabel yaitu $(97,221>2,72)$ dan nilai signifikansi (p-value) $<0,05$ yaitu ( 0,000<0,05). ( 2 ) Kepemimpinan mempunyai pengaruh yang signifikan terhadap kinerja karyawan di Palang Merah Indonesia ( PMI ) Kota Surakarta, hal ini di buktikan dengan nilai $t$ hitung > $t$ tabel yaitu 6,746 > 1,990 dan nilai signifikansi (p-value) $<0,05$ yaitu $(0,000<0,05)$. Kepuasan kerja mempunyai pengaruh yang signifikan terhadap kinerja karyawan di Palng Merah Indonesia ( PMI ) Kota Surakarta, hal ini dibuktikan dengan nilai $t$ hitung $>t$ tabel, yaitu 2,208 > 1,990 dan nilai signifikansi (p-value) $<0,05$ yaitu $(0,030<0,05)$. ( 4 ) Motivasi mempunyai pengaruh yang signifikan terhadap kinerja karyawan di Palang Merah Indonesia ( PMI) Kota Surakarta, hal ini dibuktikan dengan nilai $t$ hitung > $t$ tabel yaitu 2,214 > 1,990 dan nilai signifikansi (p-value) <0,05 yaitu $(0,036<$ $0,05)$.
\end{abstract}

Kata Kunci : kepemimpinan, kepuasan kerja, motivasi, kinerja.

\section{PENDAHULUAN}

Sumber daya manusia merupakan salah satu faktor yang berperan vital untuk mencapai tujuan organisasi. Keberadaan faktor sumber daya manusia dalam organisasi akan membawa arah pertumbuhan dan perkembangan organisasi.

Peran penting sumber daya manusia dalam organisasi bukan hanya bersifat profit orientasi saja, tetapi sumber daya manusia juga merupakan faktor penting bagi perkembangan organisasi yang bersifat non profit orientasi. Organisasi pemerintahan, organisasi sosial, maupun organisasi ekonomi sellau berupaya dalam mengembangkan sumber daya manusia di tengah pertumbuhan masyarakat yang begitu pesat. Melihat kondisi masyarakat yang selalu berkembang seiring dengan perkembangan yang ada, faktor sumber daya manusia selalu mendapatkan perhatian yang serius dalam setiap organisasi.

Palang Merah Indonesia (PMI) sebagai salah satu organisasi sosial kemasyarakatan selalu berupaya meningkatkan peranannya dalam kegiatan sosial masyarakat seiring dengan pertumbuhan 
dan perkembangan masyarakat yang ada. Masih banyak masyarakat yangmasih perlu mendapatkan perhatian, mengingat kondisi mereka yang masih memprihatinkan. Dalam upaya meningkatkan kesejahteraan masyarakat yang berada dalam kondisi memprihatinkan tersebut perlu ada dukungan organisasi yang dapat menjembatani kegiatan sosial yang dapat membantu masyarakat tersebut.

Palang Merah Indonesia (PMI) dalam upaya mencapai tujuan organisasinya tidak akan lepas dari peranan para karyawan dan relawan PMI yang selalu bekerja sama dalam upaya melaksanakan kegiatan sosial yang selama ini direncanakan. Keberadaan karyawan serta relawan PMI mempunyai peran yang besar dalam pelaksaaan setiap program kerja PMI selamam ini. Kinerja para karyawan dan relawan PMI diharapakn mempunyai jiwa sosial yang tinggi. Setiap karyawan dan relawan PMI harus mempunyai kesadaran yang tinggi mengingat prinsip kerja PMI adalah sosial, sehingga tidka semata-mata mereka bekerja karena adanya balas jasa.

Kinerja adalah satu hal yang harus diperhatikan baik dalam organisasi yang berorientasi profit maupun non profit orientasi seperti PMI.

Faktor keberadaan pemimpin, fackor kepuasan kerja dan factor motivasi adalah beberapa hal yang berpengaruh terhadap kinerja. Faktor kepemimpinan berperan penting dalam organisasi yang meningkatkan kinerja. Hal ini selaras dengan hasil penelitian yang dilakukan oleh Purwanto dan Wahyudin (2010) dalam penelitiannya yang menganalisis pengaruh kepemimpinan terhadap kinerja, menarik kesimpulan bahwa kepemimpinan memiliki pengaruh pada kinerja secara poositif dan signifikan. Hasil penelitian tersebut didapatkan bahwa keberadaan kepemimpinan yang baik akan dapat berdampak pada peningkatan kinerja.

Kinerja dapat ditingkatkan dengan adanya perhatian terhadap kepuasan kerja. Kepuasan kerja merupakan bentuk balas jasa yang diperoleh para anggota organisasi atas apa yang sudah dikerjakan pada organisasi. Kepuasan kerja yang semakin baik akan dapat meningkatkan kinerja para anggota organisasi. Pernyataan selaras dengan penelitian yang dilakukan oleh Nurdin Brasit, Muh. Yunus Amar (2010) dalam penelitiannya menarik kesimpulan bahwa kepuasan kerja memiliki pengaruh terhadap kinerja secara positif dan signifikan. Dalam penelitiannya menunjukkan bahwa semakin tinggi kepuasan karyawan atau anggota organisasi makan akan dapat berpengaruh terhadap peningkatan kinerjanya.

Kinerja selain dapat dipengaruhi oleh faktor kepemimpinan dan kepuasan kerja juga dapat dipengaruhi oleh faktor motivasi. Motivasi yang muncul dari dalam diri seseorang dapat berpengaruh terhadap hasil kerjanya. Kondisi ini sesuai dengan hasil penelitian yang dilakukan oleh Heri Prasetyo (2016) dalam menarik kesimpulan bahwa motivasi memiliki pengaruh terhadap kinerja secara positif dan signifikan. Semakin tinggi motivasi seseorang akan dapat meningkatkan kinerjanya.

\section{KAJIAN TEORI}

\subsection{Kinerja}

Menurut Mangkunegara (2007: 67), yang dimaksud dengan "kinerja (prestasi kerja) adalah hasil kerja secara kualitas dan kuantitas yang dicapai oleh seorang karyawan dalam melaksanakan tugasnya sesuai dengan tanggung jawab yang diberikan kepadanya".

\subsection{Kepemimpinan}

Harbani (2008: 202) menerangkan bahwa kepemimpinan dalam organisasi pemerintahan dapat dilihat dari beberapa aspek seperti :

1) Kemampuan mempengaruhi. 
2) Kemampuan memberikan contoh yang baik.

3) Kemampuan memotivasi bawahan.

4) Kemampuan dalam pengambilan keputusan

5) Kemampuan dalam mengelola konflik.

\subsection{Kepuasan Kerja}

Kepuasan kerja adalah sikap umum seorang individu terhadap pekerjaannya. Masalah kepuasan kerja bukanlah hal yang sederhana baik dalam arti konsepnya maupun dalam arti analisisnya karena kepuasan mempunyai konotasi yang beraneka ragam meskipun demikian tetap relevan untuk mengatakan bahwa kepuasan kerja merupakan suatu cara pandang seorang baik yang bersifat positif maupun negatif tentang pekerjaannya.

Berdasarkan definisi tentang kepuasan kerja di atas, maka dapat diketahui bahwa untuk mengetahui atau mengukur tingkat kepuasan kerja karyawan dapat digunakan indikator sebagai berikut :

a. Upah yang diterima

b. Adanya kesempatan berkembang.

c. Pelaksanaan supervisi

d. Kelompok kerja

e. Kondisi kerja.

\subsection{Motivasi}

Motivasi adalah sebagian keseluruhan proses pemberian motif kerja pada para bawahan sedemikian rupa sehingga mereka mau bekerja dengan ikhlas demi tercapainya tujuan organisasi dengan efektif dan efisien (Sedarmyanti dalam Rinduwan, 2005: 34).

\subsection{Kerangka Pemikiran}

Kerangka pemikiran dalam penelitian ini adalah :

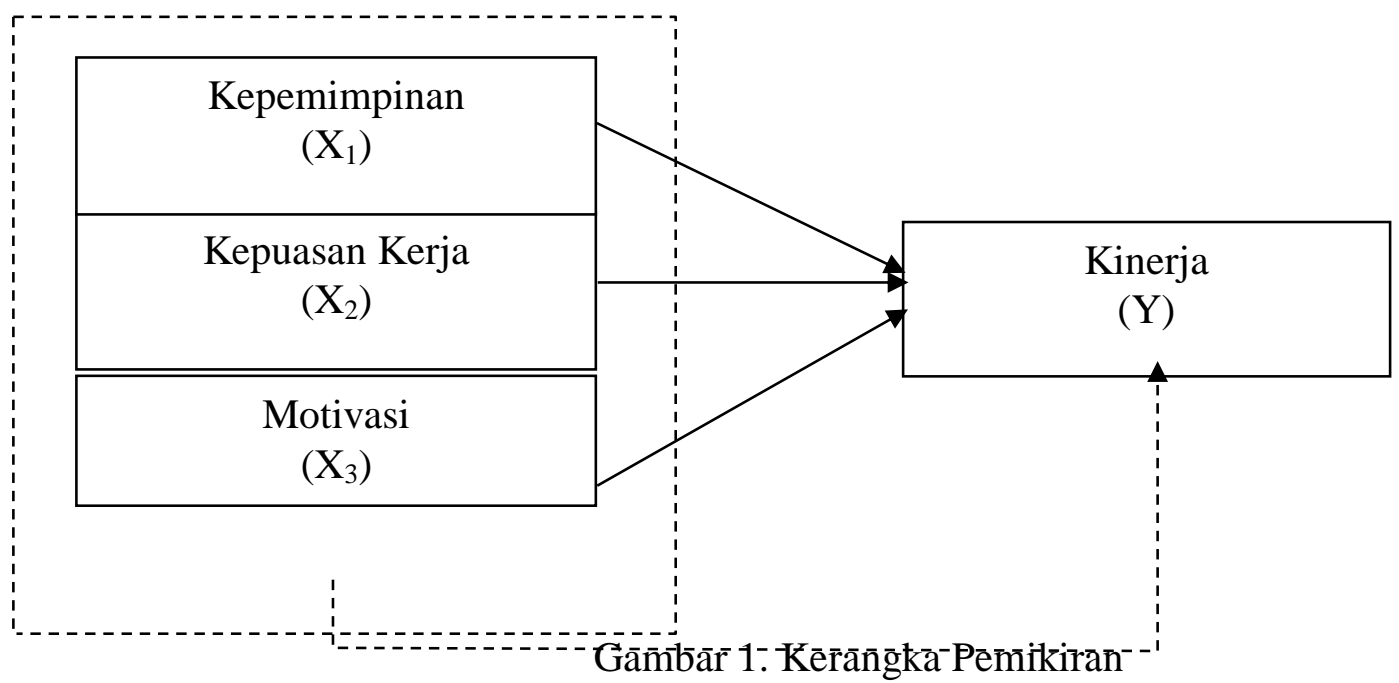




\section{METODE PENELITIAN}

Penelitian ini menggunakan penelitian kuantitatif. Tempat penelitian di Palang Merah Indonesia (PMI) Cabang Surakarta. Dalam penelitian memakai populasi semua karyawan yang ada di Palang Merah Indonesia (PMI) Cabang Surakarta. Di mana jumlah karyawan yang ada di Palang Merah Indonesia (PMI) Cabang Surakarta berdasarkan dokumen PMI Desember 2018 tercatat sebanyak 85 orang. Semua populasi diambil sebagai sampel penelitian, sehingga sampel yang diambi dalam penelitian ini 85 orang responden.

\section{PEMBAHASAN}

Hasil Uji Regresi Linier Berganda

Coefficients $^{\mathrm{a}}$

\begin{tabular}{|c|c|c|c|c|c|}
\hline \multirow[b]{2}{*}{ Model } & \multicolumn{2}{|c|}{$\begin{array}{c}\text { Unstandardized } \\
\text { Coefficients }\end{array}$} & \multirow{2}{*}{$\begin{array}{c}\begin{array}{c}\text { Standardized } \\
\text { Coefficients }\end{array} \\
\text { Beta }\end{array}$} & \multirow[b]{2}{*}{$\mathrm{t}$} & \multirow[b]{2}{*}{ Sig. } \\
\hline & $\mathrm{B}$ & Std. Error & & & \\
\hline (Constant) & $-5,707$ & 1,666 & & $-3,426$ & 001 \\
\hline Kepemimpinan & ,788 & ,117 & ,609 & 6,746 &, 000 \\
\hline Kepuasan Kerja & 248 & 112 & 205 & 2,208 & ,030 \\
\hline Motivasi & ,211 & 141 & ,213 & 2,201 & ,036 \\
\hline
\end{tabular}

a. Dependent Variable: Kinerja

Sumber : Print Out SPSS, Diolah Januari 2019

1. Kepemimpinan terhadap kinerja karyawan di Palang Merah Indonesia (PMI) Cabang Surakarta.

Pada variabel kepemimpinan berdasarkan uji diperoleh nilai $t_{\text {hitung }}(6,746)>t_{\text {tabel }}$ $(1,990)$ siginifikansi $(0,000<0,05)$, berarti Ho ditolak dan menerima Ha, artinya secara signifikan kepemimpinan mempunyai pengaruh terhadap kinerja karyawan di Palang Merah Indonesia (PMI) Cabang Surakarta. Dengan demikian dapat diketahui bahwa adanya kepemimpinan merupakan salah satu faktor yang memberi pengaruh terhadap kinerja karyawan, khususnya karyawan PMI Cabang Surakarta. Hasil penelitian ini menunjukkan bahwa dengan adanya sosok kepemimpinan yang baik akan memberi pengaruh untuk meningkatkan kinerja karyawannya. Maka dari itu, dalam upaya meningkatkan kinerja karyawan perlu adanya sosok pemimpin yang baik bagi karyawan, sosok pemimpin yang baik tersebut diantaranya adalah pemimpin yang mampu mengkoordinasikan karyawan, mampou memberi contoh yang positif, mampu memotivasi karyawan

2. Kepuasan kerja terhadap kinerja karyawan di Palang Merah Indonesia (PMI) Cabang Surakarta.

Pada variabel kepuasan kerja berdasarkan hasil uji diperoleh nilai $t_{\text {hitung }}(2,208)>t_{\text {tabel }}$ $(1,990)$ siginifikansi $0,030<0,05$, berarti Ho ditolak dan menerima $\mathrm{Ha}$, artinya secara signifikan motivasi mempunyai pengaruh terhadap kinerja karyawan di Palang Merah Indonesia (PMI) Cabang Surakarta. Dengan demikian dapat diketahui bahwa adanya kepuasan kerja yang tinggi akan memberikan peningkatan kinerja karyawan tersebut. Untuk dibutuhkan adanya perhatian terhadap kepuasan kerja, untuk itu perlu adanya pemenuhan terhadap kebutuhan karyawan sebagai bentuk balas jasa PMI Cabang Surakarta kepada karyawan. Mengingat PMI Cabang Surakarta merupakan organisasi yang bergerak di bidang kemanusiaan maka perlunya meningkatkan jiwa kemanusiaan yang lebih tinggi bagi para 
karyawannya upaya ini dapat dilakukan dengan memberikan pelatihan bagi karyawan yang masih junior serta generasi PMI untuk meningkatkan jiwa kemanusiaannya sehingga ada perasaan puas bagi para karyawan apabila mereka bisa melakukan pekerjaan-pekerjaan kemanusiaan pada sesamanya.

3. Motivasi terhadap kinerja Palang Merah Indonesia (PMI) Cabang Surakarta.

Pada variabel motivasi berdasarkan hasil uji diperoleh nilai $t_{\text {hitung }}(2,201)>t_{\text {tabel }}$ $(1,990)$ siginifikansi $0,036<0,05$, berarti Ho ditolak dan menerima Ha, artinya secara signifikan motivasi mempunyai pengaruh terhadap kinerja karyawan di Palang Merah Indonesia (PMI) Cabang Surakarta. Dengan demikian dapat diketahui bahwa adanya motivasi yang tinggi dalam diri karyawan akan memberikan peningkatan kinerja karyawan tersebut. Untuk itu dibutuhkan adanya upaya untuk membangkitkan motivasi dalam diri karyawan tersebut. Hal ini dapat dilakukan dengan mengetahui motif karyawan dalam melakukan pekerjaan, serta memberikan pemenuhan terhadap kebutuhan karyawan mulai dari kebutuhan karyawan serta sebagai organisasi kemanusiaan perlu meningkatkan motif sukarela dan jiwa sosial yang lebih tinggi kepada para karyawan.

4. Berdasarkan hasil uji hipotesis secara simultan dapat diketahui bahwa nilai $\mathrm{F}$ hitung $(97,221)>\mathrm{F}$ tabel 2,72) dan nilai signifikansi $0,000<0,05$, berarti Ho ditolak dan Ha diterima, berarti kepemimpinan, kepuasan kerja, dan motivasi secara serentak mempunyai pengaruh yang signifikan terhadap kinerja Palang Merah Indonesia (PMI) Cabang Surakarta. Hasil penelitian ini menunjukkan bahwa variabel kepemimpinan, kepuasan kerja, dan motivasi merupakan faktor-faktor yang dapat berpengaruh terhadap kinerja karyawan operasional yang ada di Palang Merah Indonesia (PMI) Cabang Surakarta.

Hasil Uji Koefisien Determinasi
\begin{tabular}{|l|c|r|r|c|}
\hline \multicolumn{5}{c}{ Model Summary } \\
Model & $\mathrm{R}$ & $\mathrm{R}$ Square & $\begin{array}{c}\text { Adjusted R } \\
\text { Square }\end{array}$ & $\begin{array}{c}\text { Std. Error of the } \\
\text { Estimate }\end{array}$ \\
\hline 1 &, $885^{\mathrm{a}}$ &, 783 &, 775 & 1,859 \\
\hline
\end{tabular}
a. Predictors: (Constant), Motivasi, Kepemimpinan, Kepuasan Kerja
Sumber : Print Out SPSS

Diperoleh nilai determinan atau adjusted $R$ Square $\left(\mathrm{R}^{2}\right)$ sebesar 0,775 artinya bahwa variasi kepemimpinan, motivasi, dan kesejahteraan terhadap kinerja Palang Merah Indonesia (PMI) Cabang Surakarta sebesar 77,5\% sedangkan sisanya sebesar 22,5\% dipengaruhi oleh faktor yang lainnya. Sehingga dapat diketahui bahwa pemilihan variabel bebas yang digunakan untuk memprediksi variabel terikat dalam penelitian ini sudah tepat, mengingat nilai koefisien determinasi dalam penelitian ini relatif besar yaitu 0,775 atau 77,5\%.

\section{KESIMPULAN}

\subsection{Kesimpulan}

Kepemimpinan, kepuasan kerja, dan motivasi berpengaruh signifikan terhadap kinerja karyawan di Palang Merah Indonesia (PMI) Cabang Surakarta baik secara parsial maupun simultan. 


\subsection{Saran}

Saran dari penelitian ini diantaranya upaya untuk meningkatkan kinerja karyawan yang ada di Palang Merah Indonesia (PMI) Cabang Surakarta perlu dukungan sosok pemimpin yang bijaksana dalam hal ini adalah pemimpin yang mampu mengatasi setiap permasalahan yang muncul dalam perusahaan dengan baik.

Dalam rangka meningkatkan kinerja karyawan di Palang Merah Indonesia (PMI) Cabang Surakarta dibutuhkan adanya perhatian terhadap kepuasan kerja, untuk itu perlu adanya pemenuhan terhadap kebutuhan karyawan sebagai bentuk balas jasa PMI Cabang Surakarta kepada karyawan. Mengingat PMI Cabang Surakarta merupakan organisasi yang bergerak di bidang kemanusiaan maka perlunya meningkatkan jiwa kemanusiaan yang lebih tinggi bagi para karyawannya upaya ini dapat dilakukan dengan memberikan pelatihan bagi karyawan yang masih junior serta generasi PMI untuk meningkatkan jiwa kemanusiaannya sehingga ada perasaan puas bagi para karyawan apabila mereka bisa melakukan pekerjaan-pekerjaan kemanusiaan pada sesamanya.

Dalam rangka meningkatkan kinerja karyawan di Palang Merah Indonesia (PMI) Cabang Surakarta dibutuhkan adanya upaya untuk membangkitkan motivasi dalam diri karyawan tersebut. Hal ini dapat dilakukan dengan mengetahui motif karyawan dalam melakukan pekerjaan, serta memberikan pemenuhan terhadap kebutuhan karyawan mulai dari kebutuhan karyawan serta sebagai organisasi kemanusiaan perlu meningkatkan motif sukarela dan jiwa sosial yang lebih tinggi kepada para karyawan.

Bagi penelitian yang akan datang dapat melakukan penelitian terkait dengan faktor-faktor yang dapat berpengaruh terhadap kinerja karyawan dengan komposisi variabel bebas yang berbeda dan obyek penelitian yang lebih komplek.

\section{DAFTAR PUSTAKA}

Dessler, Gery. 2005, Manajemen Sumber Daya Manusia, Edisi Bahasa Indonesia Jilid 2, PT. Prehallindo, Jakarata.

Ester, Berhard dan Mac. Donald. 2017. Pengaruh Kepemimpinan, Komunikasi dan Motivasi Terhadap Kinerja Karyawan Pada BP2RD Provinsi Sulawesi Utara. Jurnal EMBA. Vol. 5 No. 3 September 2017. Hal 3148-3159.

Handoko, Hani, T., 2006, Manajemen Personalia dan Sumber Daya Manusia, edisi Kedua Cetakan Kesebelas, UGM,Yogyakarta.

Hasibuan S.P. Malayu. 2007. Manajemen Sumber Daya Manusia Edisi Revisi, Bumi Aksara, Jakarta. Hariandja, Marihot Tua Efendi. 2007, Manajemen Sumber Daya Manusia, PT. Gramedia Widiasarana Indonesia, Jakarta

Ida Farida. 2010. Pengaruh Pendidikan Formal, Pelatihan dan Pengembangan Karier Terhadap Kinerja Pegawai Perempuan (Studi di Kota Bandar Lampung). Desertasi Program Pascasarjana Universitas Padjajaran Bandung.

Irianto. J, 2006, Tema-tema Pokok Manajemen Sumber Daya Manusia, Insan Cendikia, Surabaya.

James A.F; Stoner, Freeman, R. Edward; Gilbert JR, Daniel. R, 2006, Manajemen, Jilid I, Bhuana Ilmu Populer, Jakarta.

Joehana Veneranda Amaral. 2010. Hubungan Antara Komitmen Organisasi dan Gaya Kepemimpinan Terhadap Kinerja Karyawan Pada PT. Bank Negara Indonesia (Persero) Tbk. Divisi Perbankan Mikro Jakarta. Jurnal Manajemen Publik Dan Bisnis.

Kotter dan Hackett, R.D., Bycio ,P., Hausdorf, P.A., 2006. Further Assesment of Meyer and Allens Three-Component Model of Organizational Commiment. Journal of Applied Phsychology. 79 (1):15-23 
Luthans E.A., 2005, Organizational Behavior, Sixth Edition, McGraw Hill Book Co, Singapore.

Mangkunegara, Anwar Prabu. 2007, Manajemen Sumber Daya Manusia, PT. Remaja Rosda Karya, Bandung.

Mathis, Robert.L, dan John Jackson, 2006, Manajemen Sumber Daya Manusia. Salemba Empat. Jakarta.

Mariam, Rani. 2009, Pengaruh Gaya Kepemimpinan dan Budaya Organisasi Terhadap Kinerja Karyawan Melalui Kepuasan Sebagai Variabel Intervening Studi Pada Kantor PT. Asuransi Jasa Indonesia (Persero), Tesis, Magister Manajemen, Undip, Semarang, Tidak Dipublikasikan.

Misail Palagia, Nurdin Brasit, Muh. Yunus Amar. 2010. Remunerasi, Motivasi dan Kepuasan Kerja Terhadap Kinerja Pegawai Pada Kantor Pajak. Jurnal ekonomi, Magister Manajemen Universitas Hasanuddin, Makasar.

Morrow, Mc Elroy dan Blum, 2008, "Work Commitment Among Departement of Transfortation Employees, Profesional Notes," Review of Public Personnel Administration, Vol 8, No.3, p. 96-104.

Mahesa, Deewar. 2010, Analisis Pengaruh Motivasi dan Kepuasan Kerja Terhadap Kinerja Dengan Lama Kerja Sebgai Variabel Moderating (Studi Pada PT. Coca Cola Amatil Indonesia Central Java), Tesis, Magister Manajemen, Undip, Semarang, Tidak Dipublikasikan.

Nawawi, Hadari. 2006. Manajemen Sumber Daya Manusia. Gadjah Mada University Press, Yogyakarta.

Nenah dan Helmiatin. 2016. The Influences of Leadership Style and Job Satisfaction Employee Performance. IOSR Journal of Business and Management (IOSR-JBM) e-ISSN: 2278-487X. PISSN: 2319-7668, Vol 18, Issue 7 Ver. II (July 2016). PP 01-06.

Novalinda. 2014. Hubungan Antara Motivasi berprestasi dan Persepsi Kepemimpinan Kepala Sekolah Dengan Kinerja Guru. Jurnal Fakultas Psikologi Univemitos Muhammadiyah Surakarta.

Mustaqim. 2016. The Influence of Leadership Style and Motivation of Empıvees Job Satisfaction. International Journal of Economics and Finance: Vol 8. No. 10: 2016. ISSN 1916-917X E-ISSN 1916-9728.

Parwanto dan Wahyuddin, 2010. Pengaruh Faktor-Faktor Kepuasan Kerja Terhadap Kinerja Karyawan Pusat Pendidikan Komputer Akuntansi IMKA Di Surakarta. Jurnal Magister Manajemen Program Pascasarjana Universitas Muhammadiyah Surakarta.

Rino Yanuardi. 2013. Pengaruh Keterampilan Kerja dan Pengetahuan Administrasi terhadap Kinerja Pegawai Administrasi Fakultas Ekonomi Universitas Negeri Padang. Skripsi. Program Studi Pendidikan Ekonomi. Universitas Negeri Padang. Tidak Dipublikasikan.

Robbins, Stephen P. 2006, Perilaku Organisasi, Edisi Kesepuluh, Indeks Kelompok Gramedia, Jakarta.

Serly dan Sukma. 2015. Hubungan Gaya Kepemimpinan dengan Kepuasan Kerja di PT. X. Jurnal NOETIC Psychology. Vol 5. Nomor 2 Juli-Desember 2015.

Sumaryono, 2008, "Pengaruh Kepemimpinan Transformasional dan Budaya Organisasi terhadap Kepuasan Kerja Karyawan Dinas Kekaryawanan Daerah Kabupaten Karanganyar dengan Motivasi sebagai Variabel Moderating”. Tesis Program Magister Manajemen, Universitas Diponegoro, Semarang. 